\title{
Happiness: Does Culture Matter?
}

\author{
Carola Hommerich · Susanne Klien
}

\section{Introduction}

In recent years, with the emergence of 'happiness studies', an increasing number of investigations of subjective wellbeing, satisfaction and quality of life have been published across disciplines (Haidt, 2006). As Thin puts it in his article in this issue, happiness research is "about learning how people develop a sense that their lives are good" (2012: 313). Such studies frequently include cross-cultural comparisons designed to examine, for example, whether Americans are happier than Europeans, or whether marriage contributes to happiness in a similar way in Sweden and Germany. However, whether such cross-cultural comparisons are feasible and under what circumstances remain hotly debated questions.

In the course of our research on 'Happiness and Unhappiness in Japan' at the German Institute for Japanese Studies (DIJ), we have often met with difficulties applying to an Asian context theories of subjective wellbeing that originated in Western thought. To date, most theories of happiness are grounded in Western ideas of progress and fulfillment (Coulmas, 2009), as evident in Veenhoven's definition of happiness as "the degree to which an individual judges the overall quality of his life favourably" (Veenhoven, 1991: 2). But can we assume, as has been done in many other studies, that Japanese understand happiness in the same way as people from Western societies (Diener \& Suh, 1999; Veenhoven, 1993)? In Europe and the United States, happiness is something to pursue, but does this hold for Asian societies, too?

These are questions of general importance to happiness studies. Opinions differ: While most researchers in psychology, sociology, political science and economy take it for granted that cross-cultural comparisons are feasible and meaningful (e.g. Diener, 2009; Frey \& Stutzer, 2002; Layard, 2005; Veenhoven, 1993), cultural anthropologists are divided on this issue (Mathews \& Izquierdo, 2009). The traditional notion of spatialized culture is being challenged by ideas such as the "global cultural ecumene" (Appadurai, 1990; Appadurai \& Breckenridge, 1988; Hannerz, 1989) and a "world in creolization" (Hannerz, 1987), that emphasize mutual influence and the emergence of transnational interaction.

In order to probe and perhaps bridge this disciplinary gap and find common ground, we brought together experts in happiness research from various disciplines and different cultural contexts. In November 2011, we held a two-day workshop at the Japanese-German Center Berlin (JDZB), bringing together sociocultural anthropologists, psychologists, sociologists, economists, political scientists, and geographers from Germany, Japan, the Netherlands, the UK, the United States, and Switzerland. The underlying key idea was to make initial steps towards a multi-disciplinary approach combining quantitative and qualitative perspectives. Whereas the amicable atmosphere during the workshop showed the fruitfulness and potential of this approach, the prolonged in-depth discussions which evolved made it clear that we are 
still facing numerous unresolved issues when it comes to the question of the validity of crosscultural comparisons of wellbeing (see also Lu \& Gilmour, 2006; Yang, 2000).

The gist of it is summarized in this special issue, in which we aim to shed light on the complex interrelations of wellbeing and cultural context. This special issue was conceived at the above-mentioned workshop in Berlin. We wish to thank Florian Coulmas, Takayoshi Kusago, Kate Pickett, Dimitris Ballas, Yoshiaki Takahashi, Motoi Suzuki, Chris Winkler and Gisela Trommsdorff who participated in the workshop but are not represented here. We would also like to take the opportunity to express our cordial thanks to our hosts of the JapaneseGerman Center Berlin (JDZB) for excellent organization of the workshop. Finally, we would also like to thank Dan Weijers at the IJW, who strongly supported this publication.

\section{Concepts of 'culture' in different disciplines}

When trying to answer the questions whether and how culture matters for people's happiness, a first step is to provide a working definition of 'culture'. This is not easy, as evidenced by the numerous definitions used in various disciplines. According to James Clifford, culture remains "a deeply compromised idea I cannot yet do without" (1988: 10). This remark shows the dilemma inherent in the notion of culture, especially if envisaged conventionally as bounded, unitary and permanent.

The very first attempt at a systematic definition stems from anthropologist Edward Burnet Tylor, who saw culture as a "complex whole which includes knowledge, belief, art, morals, law, custom, and any other capabilities and habits acquired by man as a member of society" (Tylor, 1958 [1871]: 1). At the beginning of the 1950s, Kroeber and Kluckhohn (1952) find 164 different definitions of culture and we assume there to be more rather than less to date. Grouping them by similarity, Kroeber and Kluckhohn (1952) come up with six major classes of definitions of culture (see also Berry et al., 1992: 166; Rippl \& Seipl, 2008: 15):

1) Descriptive definitions see "culture as a comprehensive totality" (Kroeber \& Kluckhohn 1952: 85). Such definitions attempt to list any and all aspects of human life and activity thought to be connected to what encompasses 'culture'. One example is the definition by Tylor quoted above.

2) Historical definitions tend to emphasize the accumulation of tradition over time. One example would be the definition of culture by Linton (1938: 78) as "the total social heredity of mankind".

3) Normative definitions focus on shared rules and norms that govern the activity of a group of people.

4) Psychological definitions-often also adapted in sociology-emphasize psychological features which can be seen as the result of a socialization process. The focus, however, is not on the cognitions of individuals, but on the values and meanings shared by the group. Accordingly, Smith and Bond (1998: 69) define cultures as "systems of shared meanings", and Schwartz (1992) and Hofstede (1980) similarly see culture as becoming visible through "shared values".

5) Structural definitions, on the other hand, emphasize the structural manifestation or organization of a culture. This includes specific patterns, institutions or social roles which structure the social relations within a respective group. This type of definition is similar to descriptive definitions in that it incorporates cognitive, symbolic and structural elements. It goes beyond a mere 
list of customs and activities, however, and focuses on their interrelations and arrangements.

6) Genetic definitions understand culture as adaptive to the habitat of a group. It develops through social interaction and out of a creative process that is characteristic of the human species.

All of these definitions share a bounded and essentialist understanding of culture with an implicit element of relative order. In anthropology, however, the prevalent notion today is that culture no longer just refers to "the way of life of a people", but also to the array of choices individuals make from "the global cultural supermarket", to borrow Mathews' (2000: 4) terms. Numerous ethnographic studies have demonstrated that the apparent boundedness and coherence of 'a culture' has been constructed rather than naturally given (Fabian, 1990; Marcus, 1986; Thornton, 1988). This deconstruction of a spatially bounded idea of culture has resulted in a situation which Mathews puts as follows in his contribution: "In anthropology today, it is only a slight exaggeration to say that the word 'culture' can no longer be used with a straight face" (2012: 303-304).

\section{Happiness in cross-cultural comparison}

Whether or not a comparison of happiness across cultures is deemed possible depends on whether a culture-specific or a cross-cultural approach is taken. The former is based on the assumption that each culture is unique and can be described only by considering its specific setting (idiographiclemic). The latter looks for general patterns which can be extracted by comparing different cultural settings (nomothetic/etic). The definition of 'culture' within an academic discipline to some extent accounts for how the question of cross-cultural comparability of happiness is approached. While descriptive definitions and a culture-specific view dominate in cultural anthropological and ethnographic surveys, culture is most often defined as a system of shared values in psychology, sociology and political science, assuming the possibility of generalizing results across cultures. Approaches such as the cross-cultural indigenous (CCI) procedure suggested by Yang (2000) could be seen as attempts to combine these two perspectives and overcome scientific ethnocentrism by aspiring to pay more attention to emic parameters but still implement a comparative approach.

The validity of cross-cultural comparison of subjective wellbeing is also closely linked to the topic of how to measure a construct as complex as 'happiness'. The central question about measuring happiness is whether, as many studies assume, asking respondents to grade their happiness on a scale yields meaningful information. Such an approach assumes that individuals are capable of judging how happy they are. Nettle, however, reports that the subjective perception of happiness can be manipulated. In his review of several studies, he shows that the weather, finding a dime, or the physical appearance of the other people filling out the survey all significantly affect how satisfied people reported being with their whole lives (Nettle, 2005, chapter 1). Mathews makes a similar point about the differences in individual perceptions of wellbeing in his contribution to this special issue, referring to Kahneman and Krueger (2006: 18). He concludes that "it seems plausible that North Americans are not 'happier than East Asians', but are simply more willing to proclaim their happiness on a survey form" (Mathews \& Izquierdo, 2009: 7; Mathews' contribution to this special issue, 2012: 301).

This brings us to another key issue, namely the question of what happiness means to individuals. Most research on subjective wellbeing is at present based on an understanding of happiness grounded in Eurocentric ideas. In the Western intellectual tradition, happiness is 
often seen as the most important goal to strive for. This, however, does not necessarily have to be the same in Asian countries (Kitayama, Markus \& Kurokawa, 2000; Mathews, 1996). Let us assume a definition of culture as a system of shared values. Happiness would then be one value amongst others. In European or North American value systems, it might be ranked towards the top of the value hierarchy. But this cannot simply be assumed to be the same in another cultural context. Instead, a culture-relative approach is called for, in which researchers approach their object of analysis without the evaluation their own cultural background would ethnocentrically impose.

Thus, when trying to measure happiness across cultures, we first have to find a common definition of what happiness is. Whereas happiness has been used synonymously with terms such as 'subjective well-being, satisfaction, utility, well-being and welfare' (Easterlin, 2001) scholars across disciplines agree on the ambiguity of the concept of 'happiness' (Nettle, 2005: 17-20, Suikkanen, 2011: 149, Blumenberg, 1987: 215), with some arguing for understanding the term as a vague one (Feldman, 2010: 131-136; Gilbert, 2006). Indeed, finding a clear-cut definition of happiness seems difficult. Blumenberg (1987), for example, advocates respecting the subjectivity of happiness, thus claiming that we should avoid an objective determination of what happiness means:

Happiness is what an individual understands as his or her happiness; it would be a potential catastrophe for mankind if one determined for all or all determined for one or many for few or few for many determined what happiness should consist of. This is why determining what happiness is should not be left to the hands of reason; therefore, one should not seek to shed light on what happiness is by objective means (Blumberg, 1987: 216).

Nevertheless, the implicit or explicit concern with happiness has been a recurrent theme in human societies. We argue for a comprehensive examination of subjective wellbeing that connects qualitative and quantitative perspectives. The articles in this special issue try to work towards this goal.

\section{Contributions to the special issue}

The five authors differ in their perspectives on the measurability and comparability of happiness, with two of them coming from a research tradition based on qualitative methods, namely sociocultural anthropology, and three from disciplines which rely on quantitative methods - sociology and psychology.

From the viewpoint of sociocultural anthropology, Mathews and Thin both argue for the pursuit of an interdisciplinary approach to happiness by combining quantitative and qualitative methods. Both scholars argue that such an integrative approach would open up the possibility for a sensible cross-cultural comparison of wellbeing.

By discussing the limitations of statistical surveys of happiness, Mathews advocates a multi-method approach. Not only translation problems, but also the shift of the meaning of 'culture', he argues, make it difficult to compare data based on the rating of a single question. He goes on to suggest that the additional use of ethnographic interviews could provide sociocultural grounding to the uncontextualized statistics often used in psychological, sociological, and economic cross-cultural analysis of wellbeing.

Similarly, Thin emphasizes the chances of complementing quantitative with ethnographic and biographic research, in order to achieve a more holistic understanding of the social construction of happiness in cultural contexts. He argues that the reduction of the evaluation of 
individual happiness to numerical form does not give credit to the complexity of the task. Integrating quantitative measures with a narrative approach could help to discover the story behind the numbers.

Veenhoven, on the other hand, argues in favor of the comparability of happiness surveys across nations by the exclusive use of quantitative surveys. Using cross-national data to support his point, he makes a case against a cultural measurement bias of happiness.

Finally, Uchida and Ogihara present examples from cultural psychological research, identifying substantial differences in the cultural construal of happiness in European-American and East Asian contexts. Their results emphasize that cultural context does indeed matter for gaining an understanding of happiness.

\section{In lieu of a conclusion}

All in all, this volume, with contributions by representative scholars from Europe, the United States and Japan, constitutes a first interdisciplinary attempt to combine quantitative and qualitative approaches in the study of happiness. We argue that happiness scholarship requires a new conceptual language that links qualitative and quantitative methods if we are to come to grips with the complexity of subjective wellbeing. We hope that this special issue will give rise to further examinations of happiness that exceed the conventional boundaries of disciplines and respective methodologies.

\section{Authors}

Carola Hommerich

German Institute for Japanese Studies

hommerich@dijtokyo.org

Susanne Klien

German Institute for Japanese Studies

\section{References}

Appadurai, A. (1990). Disjuncture and Difference in the Global Cultural Economy. Public Culture, 2 (2): 124. http://dx.doi.org/10.1215/08992363-2-2-1

Appadurai, A. \& Breckenridge, C. (1988). 'Editors' Comments.' Public Culture, 1 (1): 1-4. http://dx.doi.org/10.1215/08992363-1-1-1

Berry, J. W.; Poortinga, Y. H.; Segall, M. H.; \& Dasen, P. R. (1992). Cross-Cultural Psychology, Research and Applications. Cambridge: University Press.

Blumenberg, H. (1987). Die Sorge geht über den Fluß. Frankfurt am Main 1987.

Clifford, J. (1988). The Predicament of Culture: Twentieth-Century Ethnography, Literature and Art. Cambridge: Harvard University Press.

Coulmas, F. (2009). Die Illusion vom Glück. Japan und der Westen. Zürich, Darmstadt: Verlag Neue Zürcher Zeitung, Primus Verlag.

Diener, E. (2009). 'The Science of Well-being.' Social Indicators Research Series, 37 Dordrecht: Springer. http://dx.doi.org/10.1007/978-90-481-2350-6

Diener, E. \& Suh, E. M. (1999). 'National Differences in Subjective Well-being.' In D. Kahneman, E. Diener, \& N. Schwarz (eds.), Well-being: The Foundations of Hedonic Psychology, New York: RussellSage: $434-450$.

Easterlin, R. A. (2001). 'Income and Happiness: Towards a Unified Theory.' The Economic Journal, 111: 465-484. http://dx.doi.org/10.1111/1468-0297.00646

Fabian, J. (1990). 'Presence and Representation: The Other and Anthropological Writing.' Critical Inquiry, 16 (4): 753-72. http://dx.doi.org/10.1086/448558 
Feldman, F. (2010). What is This Thing called Happiness? Oxford: Oxford University Press. http://dx.doi.org/10.1093/acprof:oso/9780199571178.001.0001

Frey, B. \& Stutzer, A. (2002). Happiness E Economics: How the Economy and Institutions affect Well-Being. Princeton: Princeton University Press.

Gilbert, D. (2006). Stumbling on Happiness. New York: Alfred A. Knopf.

Haidt, J. (2006). The Happiness Hypothesis. London: Arrow Books.

Hannerz, U. (1987). 'The World in Creolisation.' Africa, 57 (4): 546-59. http://dx.doi.org/10.2307/1159899

Hannerz, U. (1989). 'Notes on the Global Ecumene'. Public Culture 1 (2): 66-75. http://dx.doi.org/10.1215/08992363-1-2-66

Hofstede, G. (1980). Cultures' Consequences: International Differences in Work-related Values. London: Sage.

Kahneman, D. \& Krueger, A. B. (2006). 'Developments in the Measure of Subjective Well-Being.' Journal of Economic Perspectives, 20 (1): 3-24. http://dx.doi.org/10.1257/089533006776526030

Kitayama, S.; Markus, H. R. \& Kurokawa, M. (2000). 'Culture, Emotion, and Well-being: Good Feelings in Japan and the United States.' Cognition and Emotion 14 (1): 93-124. http://dx.doi.org/10.1080/026999300379003

Kroeber, A. A. \& Kluckhohn, C. (1952). Culture: A Critical Review of Concepts and Definitions. New York: Vintage Books.

Layard, R. (2005). Happiness: Lessons from a New Science. London: Penguin.

Linton, R. (1938). The Study of Man. New York: Appleton-Century-Crofts.

Luo, L. \& Gilmour, R. (2006). 'Individual-oriented and Socially Oriented Cultural Conceptions of Subjective Well-being: Conceptual Analysis and Scale Development.' Asian Journal of Social Psychology, 9: 36-49. http://dx.doi.org/10.1111/j.1467-839X.2006.00183.x

Marcus, G. E. (1986). 'Contemporary Problems of Ethnography in the Modern World System.' In C. James \& G. E. Marcus (eds.) Writing Culture: The Poetics and Politics of Ethnography, Berkeley: University of California Press: 165-193.

Mathews, G. (1996). What Makes Life Worth Living? How Japanese and Americans Make Sense of their Worlds. Berkeley, Los Angeles, London: University of California Press.

Mathews, G. (2000). Global Culture, Individual Identity: Searching for Home in the Cultural Supermarket. London, New York: Routledge.

Mathews, G. (2012). 'Happiness, Culture, and Context.' International Journal of Wellbeing, 2 (4): $299-312$. http://dx.doi.org/10.5502/ijw.v2.i4.2

Mathews, G. \& Izquierdo, C. (2009). Pursuits of Happiness: Well-Being in Anthropological Perspective. New York, Oxford: Berghahn Books.

Nettle, D. (2005). Happiness: The Science behind your Smile. Oxford: Oxford University Press.

Rippl, S. \& Seipl, C. (2008). Methoden kulturvergleichender Sozialforschung. Wiesbaden: VS Verlag. http://dx.doi.org/10.1007/978-3-531-90796-3

Schwartz, S. H. (1992). 'Universals in the Content and Structures of Values: Theoretical Advances and Empirical Tests in 20 Countries.' In M. Zanna (ed.), Advances in Experimental Social Psychology, Vol. 25. Orlanda, FL: Academic Press: 1-65.

Smith, P. B. \& Bond, M. H. (1998). Social Psychology across Cultures. London: Prentice Hall Europe.

Suikkanen, J. (2011). 'An Improved Whole Life Satisfaction Theory of Happiness.' International Journal of Wellbeing, 1 (1): 149-166. http://dx.doi.org/10.5502/ijw.v1i1.7

Thin, N. (2012). 'Counting and Recounting Happiness and Culture: On Happiness Surveys and Prudential Ethnobiography.' International Journal of Wellbeing, 2 (4): 313-332. http://dx.doi.org/10.5502/ijw.v2.i4.3

Thornton, R. J. (1988). 'The Rhetoric of Ethnographic Holism.' Cultural Anthropology, 3 (3): 285-303. http://dx.doi.org/10.1525/can.1988.3.3.02a00050

Tylor, E. B. (1958 [1871]). The Origins of Culture. New York: Harber \& Row. 
Uchida, Y., \& Ogihara, Y. (2012). 'Personal or Interpersonal Construal of Happiness: A Cultural Psychological Perspective.' International Journal of Wellbeing, 2 (4): 354-369.

http://dx.doi.org/10.5502/ijw.v2.i4.5

Veenhoven, R. (1991). 'Is Happiness Relative?' Social Indicators Research, 24 (1): 1-34. http://dx.doi.org/10.1007/BF00292648

Veenhoven, R. (1993). Happiness in Nations: Subjective Appreciation of Life in 56 Nations 1946-1992. Rotterdam: Erasmus University, RISBO, Center for Socio-Cultural Transformation.

Veenhoven, R. (2012). 'Cross-national Differences in Happiness: Cultural Measurement Bias or Effect of Culture?' International Journal of Wellbeing, 2 (4): 333-353. http://dx.doi.org/10.5502/ijw.v2.i4.4

Yang, K. S. (2000). 'Mono-cultural and Cross-cultural Indigenous Approaches: The Royal Road to the Development of a Balanced Global Psychology.' Asian Journal of Social Psychology, 3 (3): 241-263. http://dx.doi.org/10.1111/1467-839X.00067 